\title{
HEGELIAN ANALYTIC PHILOSOPHY: P. REDDING'S READING OF HEGEL
}

\author{
AgEMIR BAVARESCO ${ }^{1}$ AND ANDREW COOPER ${ }^{2}$ \\ Pontifical Catholic University of Rio Grande do Sul. Brazil \\ University of Sydney
}

ABSTRACT: The classic analytic tradition associated the philosophy of George Berkeley with idealism. Yet in terms of the German Idealismus, Berkeley was no idealist. Rather, he described himself as an "immaterialist”. In the classic analytic tradition we find a misunderstanding of the German Idealismus. This paper will suggest, through reference to the work of Paul Redding, that Hegel's Phenomenology of Spirit presents Idealismus as that which reconciles objectivity and subjectivity in the experience of consciousness. Hegel's Phenomenology develops this idea in the elaboration of a remarkably novel theory of consciousness. For Hegel, the conditions of the possibility of the objects of experience are a dialectical movement between consciousness and the object, or immediacy and mediacy. In the whole movement of consciousness we have the logic of contradiction working at the back of phenomenological experience that Hegel will make explicit in the Science of Logic, a logic that involves the thinker becoming consciously aware of their own thought processes. Yet Hegel's Logic is different from the common meaning of 'logic'. His Logic is not a formal approach to valid inference but captures the method and the moments and movement of logic. For Hegel, the great problem of classical logic is the immobility of the categories. This paper proposes that Hegel's 'holism' entails the description wherein Logic, Nature, and Spirit are articulated as a whole in dialectical movement.

KeYwords: Analytic Philosophy. Phenomenology. Logic Model. Method. Holism.

1 Professor at Pontifical Catholic University of Rio Grande do Sul (PUCRS), Brazil. CV: http://lattes.cnpq.br/6597683266934574

* This paper is the result of research done at the University of Sydney under the direction of Prof. Paul Redding to which I am deeply grateful for the comments and observations made to the text.

${ }^{2} \mathrm{PhD}$ Candidate, University of Sydney 


\section{Introduction}

In this paper we will follow Paul Redding in his Hegelian overview beginning with the Phenomenology of Spirit, continuing with the Science of Logic and ending with the Encyclopedia of the Philosophical Sciences. Redding provides us with an important holistic approach that articulates the method of Hegel's thought with his logical mediation and the transition to Realphilosophy. We suggest that Redding's exposition picks up the correct movement of the Hegelian Idea, which is the Idea in movement throughout the conceptual content. Our aim is to present Redding's works ${ }^{3}$ and to stress some ideas and issues that he presents from the standpoint of analytic philosophy.

Firstly, we need to understand what Idealismus is for Hegel. The classic analytic tradition associated the philosophy of George Berkeley with idealism. Yet in the German Idealismus, Berkeley was no idealist. Rather, he described himself as an "immaterialist”. In the classic analytic tradition we find a misunderstanding of the German Idealismus. For the "German tradition Idee (plural, Ideen) did not refer to the sort of subjective mental representations that Berkeley, in common with the British empiricists, called 'ideas' (for this notion, the Germans reserved the term Vorstellung, usually translated as 'representation')” (id. p. 3) ${ }^{4}$. In the German tradition, ideas are also not “forms” as Platonic entities in any enclosed mental sphere.

The concept of German Idealismus requires the unification of the modern subjective conception of consciousness, the "mechanical" worldview, and Greek speculative thought. "For Hegel, in particular, this came to take an historical dimension in which Greek speculative philosophy could be seen as set on a trajectory in which the modern conception of an atomic subject standing opposed to its 'object' was somehow generated from the matrix of ancient thought, bringing about both the freedom and alienation that characterized modern life” (id. p. 3-4). This is the challenge for Hegel: to reconcile modern subjectivity with ancient objectivity. In other words, "for Hegel, the task facing moderns was that of somehow bringing about a reconciliation of the alienated modern subject with the world without sacrificing its unique form of freedom” (id. p. 4).

\footnotetext{
${ }^{3}$ Paul Redding. "Georg Wilhelm Friedrich Hegel”. Oxford Companion to $19^{\text {th }}$ Century German Philosophy, ed M. Forster and K. Gjesdal, forthcoming 2013; and Paul Redding. "Hegel's Anticipation of the Early History of Analytic Philosophy”. The Owl of Minerva. 42 (1-2):18-40 (2010-11).

${ }^{4}$ Paul Redding. “Georg Wilhelm Friedrich Hegel”. Oxford Companion to $19^{\text {th }}$ Century German Philosophy, ed M. Forster and K. Gjesdal, 2013.
} 
Phenomenology of Spirit is the presentation of this true Idealismus that reconciles objectivity and subjectivity in the experience of consciousness.

\section{Phenomenology: Analytic Philosophy and Logic Model}

In the following sections our aim is to identify the specific moments of the movement of Hegel's logic. We will break down each moment and explain its significance, exploring each moment under a separate heading.

\section{a. Phenomenology and early analytic philosophy ${ }^{5}$}

Redding reminds us that "Kant had thought of objects of experience as necessarily having conceptual (as well as spatio-temporal) form, but non-conceptual ('intuitional') content” (Redding, 2010-11, p. 19). In contrast, Hegel elaborates a new model of experience of consciousness. The conditions of the possibility of the objects of experience (see Kant) are in Hegel as a dialectical movement between consciousness and the object, or immediacy and mediacy: "When we reflect on this difference, we find that neither one nor the other is only immediately present in sense-certainty, but each is at the same time mediated: I have this certainty through something else, viz. the thing” (Hegel, 1977, p. 59 ${ }^{6}$ ). This movement constitutes the content of the object, "because of the constitutive contradiction at its centre" (Redding, 2010-11, p. 20). The immediate shape of consciousness is "sense-certainty" and "the objects of sense-certainty show clear parallels with the sense-data of Bertrand Russell's early philosophy” (id. p. 20). Hegel appeals to the model of the demonstrative pronoun, "this" - "I am in it only as a pure 'This', and the object similarly only as a pure 'This' (Hegel, 1977, p. 58) - in order to capture the immediacy of the contents of sense-certainty. "Russell too appeals to demonstratives as the proper names of sense data (...) then allows us to think of Hegel as, in some way, anticipating Wilfrid Sellars’s celebrated critique of the ‘Myth of the Given’ ” (id. p. 20).

We have different interpretations of the Phenomenology's opening chapters ${ }^{7}$, for example, Kenneth Westphal, in Hegel's Epistemology: a Philosophical Introduction to the Phenomenology of Spirit, 2003, takes the contemporary analytical epistemological

\footnotetext{
${ }^{5}$ Paul Redding. "Hegel's Anticipation of the Early History of Analytic Philosophy”. The Owl of Minerva. 42 (1-2):18-40 (2010-11).

${ }^{6}$ G. W. F. Hegel, Phenomenology of Spirit, trans. A. V. Miller, Oxford: Oxford University Press, 1977.

7 See Robert B. Pippin. Hegel's idealism: The satisfactions of self-consciousness. Cambridge University Press, 1989. Terry Pinkard. Hegel's phenomenology: the sociality of reason. Cambridge University Press, 1996.
} 
approach. Redding explores the relationship between Hegel and analytic philosophy, particularly semantics and the nature of reference. He agrees with Westphal's epistemological reading and thinks that the parallels with analytic theories of reference are illuminating. Henry Harris, in Hegel's Ladder: the pilgrimage of Reason, 1997, qualifies "sense-certainty" as pre-philosophical in everyday life. He compares consciousness like a countrywoman who is at home in her world of singular things and their proper names, to which we can unproblematically refer. “In Hegel’s dialectic, upon reflection consciousness comes to recognize its initial conception of what is given to it as problematic (...). Similarly, the conception of language as names to be attached to things is also problematic. [S]uch ideas seem to play a large role in the history of early analytic philosophy (...) the progress of these two ‘dialectics' may show similarities” (id. p. 21).

Experience, Language and Reference: Consciousness progresses through a series of shapes in the opening chapters of the Phenomenology. "The history of early analytic conceptions of reference might also be thought (...) the properly referring parts of speech which express thought” (id. p. 21). In Hegel a simple experiment involves the use of language, for example, there are singular references of words like “this”, “now”, “here”. He interprets that what "I mean" or "my opinion" cannot be what is said, or written down, because the "absolutely singular, wholly personal, individual things” cannot be expressed. “The semantic contents of words such as 'this', 'here', and 'now' are properly thought of not as names but as universals, words expressing concepts, and it is this fact that is made explicit in 'perception' "(id. p. 22).

The contradictory "Thing” of Perception: The object of perception is different from the object of sense-certainty. Hegel describes this object as a "Thing" (das Ding) articulated with many properties. He gives as the example, "this salt" that is constituted of properties such as: white, tart, cubical etc. These properties are different and relate to others as their opposites; finally they inhere in a "one" that excludes other ones. Aristotle in the Categories also conceived the "Thing" of perception that endures and remains in this change. For Aristotle the "Thing" of perception is a substance with a tensional concept, either universal or particular. For Hegel the "Thing” of perception also has a complex or a contradictory concept in the experience of consciousness.

When we replace the proper name with a description there is a parallel between consciousness in Hegel's presentation and the semantic assumptions of the early analytic philosophy we find in Russell. "But the descriptivist analysis of perceptual content in 
Hegel's account fails, as does the descriptivist analysis of proper names in Russell's account, and both these failures are bound up with internal problems with the Aristotelian infrastructure of this thought” (id. p. 24).

From Perception to Understanding or from Russell to Quine: The transition from perception to understanding "involves a form of cognition that employs concepts whose contents are no longer determined by sensuously given properties” (id. p. 29). Redding refers to Hegel's Lectures on the Philosophy of Spirit, 1827, in the discussion of "representation", wherein Hegel describes the content of representation as "given" and immediately found. The transition from "a sensible, immediate givenness” to determined content, "it is only in thought that concepts function in a way such that they are no longer determined by some given sensuous content” (id. p. 29). Redding suggests that a model for this is to be found in Leibniz's critique of Locke’s “Myth of the Given”. Leibniz criticizes the Lockean conception of “clear and distinct ideas”, but for Leibniz they are “clear and confused”, because we need to employ analytic methods, a technique which Leibniz had called “analysis” (see p. 29).

In the chapter, "Force and the Understanding”, Hegel describes the "play of forces" that stands in opposition to each other, the "absolute interchange" of forces. This is the difference in contrast to perception wherein the world is a static world of things. Now is stressed the movement of contradiction of the play of forces, surpassing the principle of identity and the atomistic assumptions, into the relation between opposed forces. "The discussion of the play of forces has brought out the error behind the atomistic assumptions with which consciousness has been operating, the assumptions that an object's identity can be conceived in abstraction from its relations” (id. p. 30).

Redding has presented the Hegelian semantic equivalent of understanding's "object” in the early history of analytic philosophy. He suggests that "a novel way around the problem of "the Given” had been put forward by W. V. O. Quine” (id. p. 30). In this sense “Quine introduces the 'semantic holism' that Russell had originally reacted against in his idealist predecessors, and this is part of the reason behind Richard Rorty's claim of the 're-Hegelianizing' of analytic philosophy” (id. p. 31). Quinean's holism "has been an important contributor to what I [Redding] have referred to elsewhere as the 'return of Hegelian thought' within analytic philosophy in the second half of the $20^{\text {th }}$ century” (id. p. 32). 


\section{b. The Model and the Logic of the Consciousness in the Phenomenology of Spirit}

Phenomenology, according to the text's original title, is a "science of the experience of consciousness". However, what is the model of consciousness that Hegel proposes to describe in the path of the Absolute Knowing? It is neither the Cartesian identification of thinking and consciousness nor Reinhold's fixed separation between the individual thinker (the subject) and the "object" of which that subject is conscious. Hegel wants to surpass this model subject-object. There are other models such as the model of self-knowledge wherein the subject/object are identical; or a type of collective thinking, undertaken by a community in which the unity of the 'thinking subject' is distributed over a plurality of different subjects; or a type closer to a religious conception of some sort of 'participation' of the individual conscious subject in the mind of a God (cf. id p. 5) ${ }^{8}$. All of these models and dimensions of consciousness play a role in Hegel's alternative to the simple subjectobject model, says Redding.

Experience of contradiction of consciousness: There is normative shape or logical movement working in the back of the consciousness in order to supersede the contradiction subject-object and instantiate the reconciliation of the experience of consciousness. According to Redding, while Hegel's interpretation of phenomenology "is a highly innovative one, we might think of the basic conception behind his idea as a Kantian one” (id. p. 6).

Kant thinks that empirical knowledge is conditioned by structures of the individual knower that are both intuitional and conceptual. For this reason the object cannot be thought of as it is "in itself", and that is why we don't know the world "as it is in itself". "This project of traditional metaphysics was then to be replaced by a type of selfknowledge - knowledge by the thinker of its own constitutive conditions as a thinker" (id. p. 6).

In each step of the experience of consciousness, Hegel resolves the contradictions that Kant alludes to but did not recognize were reconcilable. Hegel presents the contradiction that is the implicit logic in the experience of consciousness and by the

8 Paul Redding. “Georg Wilhelm Friedrich Hegel”. Oxford Companion to $19^{\text {th }}$ Century German Philosophy, ed M. Forster and K. Gjesdal, 2013. 
dialectical movement it becomes the explicit shape of consciousness in the extended way of the Phenomenology of Spirit.

Contradiction in the consciousness as sense-certainty: In Chapter 1, consciousness struggles "to make its implicit criteria for objecthood explicit to itself by making them in turn objects of consciousness has resulted in contradiction”. The contradiction here is this: The immediate singular object is opposed to the universal. "When I say: 'a single thing', I am really saying what is from a wholly universal point of view, for everything is a single thing”. As a result, instead of being "this", "now", "here”, the object will be the "thing”.

Contradiction in the consciousness as perception: The object of "perception" is conceived as thing: "This determinateness, which constitutes the essential character of the Thing and distinguishes it from all others, is now defined in such a way that the Thing is thereby in opposition to other Things, but is supposed to preserve its independence in this opposition” (Hegel, I 125, p. 75). This opposition collapses this experience and the new shape emerges from the perception.

Contradiction in the consciousness as understanding: This experience grasps the contradictions as a play of forces. "This true essence of Things has now the character of not being immediately for consciousness; on the contrary, consciousness has a mediated relation to the inner being and, as the Understanding, looks through this mediating play of Forces into the true background of Things. The middle term which unites the two extremes, the Understanding and the inner world is the developed being of Force” (Hegel, $\uparrow$ 143, p. 86-7).

After this experience, Chapter 4 realizes the change to self-consciousness, that is "something like a transition from all pre-Kantian conceptions of the objects of philosophy to a Kantian one, or, more specifically, to the form of transformed Kantianism found in the work of Fichte” (Redding, id. p. 7). We have here the "struggle of recognition” between two self-consciousnesses, a struggle that reveals the contradiction by the asymmetry of its instantiation in the form of the master and slave.

The dialectic method characterizes these experiences that progress to reason (Chapter 5), spirit (Chapter 6), religion (Chapter 7) and Absolute Knowing (Chapter 8). An immanent and implicit logic works during all the movements and moments of the

\footnotetext{
${ }^{9}$ G. W. F. Hegel, Phenomenology of Spirit, trans. A. V. Miller, Oxford: Oxford University Press, 1977, $q$ 110, p. 66.
} 
consciousness. The Absolute Knowing is the whole in movement, in other words, what was implicit now becomes explicit because "the True is the whole. But the whole is nothing other than the essence consummating itself through its development. Of the Absolute it must be said that it is essentially a result, that only in the end is it what it truly is” (Hegel, Preface, ๆ 20, p. 11).

We have in the whole movement of consciousness the logic of contradiction working at the back of phenomenological experience that the Science of Logic will make explicit: "the thinker becomes consciously aware of its own thought processes" (id. p. 8).

\section{The Method of the Science of Logic}

The meaning of "logic" today is different to Hegel's Logic. "Hegel did not have in mind that type of formal approach to valid inference that we now think of as the subject matter of logic” (Redding, p. 8). In his logic it is important to grasp the method and the movement of logic. The great problem from classical logic was the immobility of the categories, that is, the non-movement of whole categories. Hegel begins with this kind of thought that qualifies as (a) the logic of "understanding”. But this is only one moment of the movement of the logical method that needs to develop two other moments: (b) the negativity of dialectic which brings the fixed determination of the understanding into contradiction and (c) the positivity of speculation which "apprehends the unity of the determinations in their opposition, the affirmative that is contained in their dissolution and in their transition”"10. "It is only these three interconnected dimensions of 'logic' that gives life to thought” (id. p. 9), concludes Redding. The Science of Logic is a network of concepts that are in relationship to each other by the method of the whole in movement. We point out in the Science of Logic aspects of these different moments of the implementation of the Hegelian method.

1 - In the first chapter of Book 1, "Being", Hegel describes the "know how" of his logical method with the dialectic between: Being-Nothing-Becoming. He commences with Being because it is the "immediate". Being does not have presuppositions or determinations. However, the movement of determination of thought needs the opposition to something else, that is, "Nothing”. Now it commences the relation between Being-

\footnotetext{
${ }^{10}$ G. W. F. Hegel. The Encyclopaedia Logic. Part I of the Encyclopaedia of Philosophical Sciences with the Zusätze, trans. T. F. Geraets, W. A. Suchting, and H. S. Harris, Indianapolis: Hackett, 1991, § 82.
} 
Nothing that is the mediation. It apprehends the unity of their opposition by the category "Becoming”. This moment is a more inclusive determination than the bare Being. The "cell matrix" of the whole logic as described here, that is, the relation between immediacymediation, involves movement. The first concept leaves and returns from the other by the dialectic movement as a new conceptual content always open for "another more inclusive determination that is now affirmed” (id. p. 9).

2 - In Book 2, "The Doctrine of Essence", Hegel describes the dialectic of "essence” and "appearance”. Redding compares this moment with the "play of forces" from the Phenomenology of Spirit. In other words, it refers to the whole relation of thought through the structures of reflexion. Now the object of logic becomes translucent by the "play of reflexion" between "essence" and "appearance”, instantiating the relation of determinate negation (cf. id. p. 9).

3 - In Book 3, “The Doctrine of Concept”, Hegel introduces the debate about formal logic in Chapters 2 ("The Judgement”) and 3 ("The Syllogism”). First, what does "concept" mean for Hegel? It is not "the type of empirical conceptual representation applied in a judgement”. Hegel's model for “concept” is the idea "that Kant thought as ultimately presupposed by the application of any empirical concept - the concept ' $\mathrm{I}$ ' (id. p. 10). Redding examines the concept "I" in relation to the theme of the "struggle for recognition" in the Phenomenology of Spirit: the "I" emerges from two selfconsciousnesses that will later be constituted by other moments of the developments of spirit. "Possession of the concept 'I' will thereby be dependent on the possession of many other concepts (....). Thus "I” will be no self-sufficient atomic concept; it must ultimately be conceptually related to many other concepts, and Hegel purports to unpack this implicit content via an examination of the way concepts function in judgments and syllogisms” (id. p. 10) ${ }^{11}$.

This structural web of concept involves three moments: Universal, Particular and Singular. Kant opposed the general concepts with singularity, thus he needs the intuitive contents in order to make concepts determinate. Hegel also recognizes that the universal concepts are indeterminate, which is the reason that they need to become determinate. To achieve determinacy it is not necessary to add something non-conceptual as Kant elaborated. Rather, Hegel introduces particularity: “a 'particular' is to be grasped in terms

${ }^{11}$ See Robert Brandom. Articulating reasons: An introduction to inferentialism. Harvard University Press, 2009. 
of the genus-concept specifying the kind instantiated, and is to be distinguished from something singular” (id. p. 10). This is important to understand for Hegel's account of judgments and inferences. In Chapter 2, Hegel presents two different approaches to the logical structure of judgment: (a) Subject and predicate terms are "considered complete, each on its own account, apart from the other"12; and (b) Subject and predicate terms receive their determination "in the judgment first" ${ }^{31}$. The first structure reflects the "approach of traditional term logics like that of Aristotle", while with the second one shows that "the components of the judgment are treated in terms of their contribution to what is usually thought of as their propositional content” (id. p. 11).

For Hegel the syllogism is the truth of the judgment, "a claim that might be read in terms of an 'inferentialist' account of judgment content” (id. p. 11). He assumes the classical logic from Aristotle that affirms the subject term as itself a predicate, such that " $\mathrm{S}$ is P". But he changes this form by using "S" and "P”, following Leibniz. Then, "treating this relation between subject and predicate as a type of identity $-\mathrm{S}=\mathrm{P}-$ Hegel transforms the traditional syllogism of being into the "syllogism of reflection". "This change in attitude to judgments and syllogisms reflect deep metaphysical differences between ancient and modern thought” (id. p. 11). According to Redding, “it is clear that for Hegel, Leibniz's logic, which he treats at the point of transition between these two syllogistic forms, actualizes the dialectical self-undermining potential that is implicit in Aristotle's whole logical project” (id. p. 11).

Hegel shows that the "I" from which the determinations of subjective logic are posited by a subject, needs now to be itself "the product of an objective historically developed form of life" (id. p. 13). The subjective Logic describes the historical development of formal logic from Aristotle to Leibniz. Hegel presented this formal logic as ossified material of thought that needs to become fluid material in order to regain the fluidity of the concept. The "I” from "Subjectivity” was determined as "judgment” and "syllogism". Now this process is developed through the world "such that elements of the world can be understood as configurations of thought's articulations” (id. p. 13). Section Two, “Objectivity” and Section Three, “The Idea” "must be read as attempting to exhibit the 'content' able to function as objective conditions for this very type of thought" (id p. 13). That is the logical structure of a series of forms: mechanical, chemical and organic

\footnotetext{
${ }^{12}$ G. W. F. Hegel. Science of Logic, trans. A. V. Miller, London: Allen and Unwin, 1969, p. 625.

${ }^{13}$ Id. p. 627.
} 
processes which will constitute the "real-philosophy" (Philosophy of Nature). And the "Idea" is the logical structure realized in the Philosophy of Spirit. This whole process is the return to the objectivity of Logic and the transition to Realphilosophy.

\section{Hegel's Holism or the Systematic Real Philosophy}

Hegelian holism is the description wherein Logic, Nature and Spirit are articulated as a whole in a dialectic movement. The Logic was described above and we must present the other two moments of the philosophical syllogism.

a) Philosophy of Nature forms part of the Encyclopedia of the Philosophical Sciences together with Logic and Philosophy of Spirit. The Philosophy of Nature contains the "presentation of the state of the natural sciences in Hegel's time [that] is generally thought to have little more than historical interest” (id. p. 14). Redding shows us one aspect of the philosophy of nature by referring to the objection made by the philosopher $\mathrm{W}$. T. Krug. Krug argues that Hegel attempts to “deduce” the natural world only from logical considerations before empirical science. He affirms that such idealism must deduce from the idea of "the Absolute", all contingent phenomena, including the actual pen with which he was writing his critique. Hegel responded that Krug made the critique from "the common understanding” that posits the Absolute on the same level with the finite, which would entail that the determinacies that are a topic of philosophical discussion belong to the philosophy of nature. However this does not include the pen of Mr. Krug. Redding summarises this question very well: "Rather than 'deducing' the entire content of empirical reality, philosophy of nature takes as its subject matter the results of the natural sciences and tries to find within these results the sorts of categorical structures deduced in the logic” (id. p. 14). For Hegel the question is to apprehend the speculative meaning of the natural sciences in his time, or the dialectic method that articulates the parts with the whole as the natural organism.

b) Philosophy of Spirit consists in subjective spirit, objective spirit, and absolute spirit. 1) Subjective spirit begins with the more immediate anthropological determination that is the soul (Seele) as the "feeling soul". After we have the phenomenological experience the consciousness knows its opposition as a contradiction subject-object in modern philosophy. Ultimately spirit is described as "psychology", referring to the "rational dimension of the life of the mind" in its normative sense "rather than naturalistic 
[life]” (id. p. 15). The soul in its immediacy is included in the whole dynamic of the normative mediation which is the condition to become objective spirit or institutional, social and historical organisations.

c) Objective spirit describes the way that spirit is objectified in history which will be later called Philosophy of Right. It begins with “abstract right” wherein Hegel presents the way that liberty becomes exterior in the objects and the struggle of persons by mediation of a contract that is a form of recognition. Afterwards, he passes to the moment of "morality" "conceived more or less as an internalization of the external legal relations" (id. p. 16). Morality makes the mediation of subjective liberty that is the warrant for the constitution of citizenship in the moment of "ethicity" (Sittlichkeit). We have three institutions of liberty: the person, the subject and citizenship, which are articulated as spheres modelled on different "syllogistic" configurations. This syllogism of liberty is “Hegel’s 'logical' schematisation of the modern 'rational' state” (id. p. 16), articulating the three institutions of liberty in a holistic way. Ultimately, the "world history" (die Weltgeschichte) is the final part of objective spirit wherein Hegel presents the criterion of the peoples becoming a state enabled to relate internationally. It depends on the "degree to which they enable the development of a universalizable self-consciousness capable of rationality and freedom” (id. p. 17). It is important to observe that Hegel does not destroy the particular people in his holistic understanding of world history. Rather, he preserves, or better, guarantees the sphere of particular peoples within the syllogistic and holistic configuration of world history. Redding concludes this part with a special claim that responds to many prejudices about Hegel's particular analysis of the history of peoples: “It must be stressed that, as with philosophy of nature, philosophy of history is not meant to somehow deduce actual empirical historical phenomena like Krug's pen; rather, it takes the results of actual empirical history as its material and attempts to find exemplified within this material the sorts of categorical progressions of the logic” (id. p. 17).

d) Absolute Spirit comprehends three moments: art, religion and philosophy. The aesthetic experience is not the experience of the beauty of nature as in the Kantian conception, but for Hegel "aesthetics is primarily about art, and the art of historical peoples is understood in terms (...) to bring before consciousness the totality of what is” (id. p. 18), the shape of the Absolute is intuited in "symbolic art" (pantheistic religions), in "classical art” (Greek and Roman), and in "romantic art". The latter "is characterized by the depth of a form of subjective consciousness that is largely missing in antiquity” (id. p. 18). This 
shift introduces the moment of religion that grasps the Absolute as "representation" (Vorstellung) that is the form of God in the Trinitarian Christian Religion. Finally, the transition to philosophy is the moment that grasps the Absolute as the concept. It means to apprehend the three forms of Absolute in the immediate form as intuition, later by mediation of representation, and finally as the holistic concept itself.

The issue about religion divided the Hegelian followers into "left" and "right". They questioned "whether Hegel was signalling the overcoming of religion by a fundamentally secular philosophy, or a transition to some higher, more rational form of religion” (id. p. 20). According to Redding, "Hegel identified himself as a Christian (...) without this element we have only the dead ossifications of reason, rather than reason itself, and the inability to conceptually distinguish the realms of nature and spirit” (id. p. 20).

Redding assists us to see the unity of the Hegelian system, beginning with the implicit logic of the Phenomenology, the explicit logic of the Science of Logic, and moving on to his holistic account of Logic, Nature and Spirit in his Encyclopedia of the Philosophical Sciences. We have tried to show that Redding's account of Hegel's philosophical trajectory clarifies Hegel's novel approach to logic, to wit, that logic consists in grasping the method and movement of the implicit logic of thought. Classical logic held the categories to be immobile, static, and Hegel's holism puts ancient logic into motion by describing the movement wherein Logic, nature, and Spirit as a whole in dialectical movement. Hegel's Idealismus sets before philosophy a radically new challenge: reconciling objectivity and subjectivity in the experience of consciousness.

\section{References}

BRANDOM, Robert (2009). Articulating reasons: An introduction to inferentialism. Harvard University Press.

HeGEL, G. W. F. (1977). Phenomenology of Spirit. Trans. A. V. Miller, Oxford: Oxford University Press.

— (1969). Science of Logic. Trans. A. V. Miller, London: Allen and Unwin.

- (1991). The Encyclopaedia Logic: Part I of the Encyclopaedia of Philosophical Sciences with the Zusätze, trans. T. F. Geraets, W. A. Suchting, and H. S. Harris, Indianapolis: Hackett.

PIPPIN, Robert B. (1989). Hegel's idealism: The satisfactions of self-consciousness. Cambridge University Press. 
PINKARD, Terry (1996).Hegel's phenomenology: the sociality of reason. Cambridge University Press.

REDDING, Paul (2007). Analytic Philosophy and the Return of Hegelian Thought, Cambridge: Cambridge University Press.

— (2010-2011). “Hegel’s Anticipation of the Early History of Analytic Philosophy”. The Owl of Minerva. 42 (1-2):18-40.

- (2013). “Georg Wilhelm Friedrich Hegel”. Oxford Companion to $19^{\text {th }}$ Century German Philosophy, ed M. Forster and K. Gjesdal.

Recibido: 31/05/2013

Aceptado: 02/07/2013 